\title{
Pengaruh Penambahan Sodium Tripolyphosphate Terhadap Karakteristik Tepung Buru Hotong (Setaria italica L Beauv.) Fosfat
}

\author{
The Effect of Sodium Tripolyphosphate on the Characteristics of Buru Hotong Flour \\ (Setaria italica L. Beauv.) Phosphate
}

\author{
Rachel Breemer ${ }^{1}$, Trisonda Sigmarlatu ${ }^{2}$, Febby J. Polnaya ${ }^{1, *}$ \\ ${ }^{1}$ Jurusan Teknologi Hasil Pertanian, Fakultas Pertanian Universitas Pattimura, Jl. Ir. M. Putuhena, \\ Kampus Poka, Ambon 97233, Maluku, Indonesia \\ ${ }^{2}$ Program Studi Teknologi Hasil Pertanian, Jurusan Teknologi Hasil Pertanian, Fakultas Pertanian \\ Universitas Pattimura, Jl. Ir. M. Putuhena, Kampus Poka, Ambon 97233, Maluku, Indonesia
}

*Penulis korespondensi: Febby J. Polnaya, e-mail: febby.polnaya@ faperta.unpatti.ac.id

Tanggal submisi: 01 Juli 2020; Tanggal penerimaan: 10 Oktober 2020

\begin{abstract}
This study aimed to characterize phosphate-modified buru hotong flour modified used sodium tripolyphosphate (STPP). Buru hotong flour was phosphorylated at $45^{\circ} \mathrm{C}$ with STPP concentration of 10 , 15.20 , and $25 \%$ for 30 minutes. Observations were conducted on the physicochemical properties of native buru hotong flour and its derivatives, including phosphorus levels, degree of substitution (DS), moisture content, ash content, swelling power, solubility, and amylose content. The results showed that the phosphorus content of buru hotong phosphate flour increased (0.023-0.077\%) with the DS ranged between 0.001-0.004. Phosphorus and DS levels indicated the substitution of phosphate groups. Substituted phosphate groups increased the moisture content (6.92-10.23\%), ash content (0.37-0.84\%), swelling power (10.16-15.63\%), solubility (29.22-46.2\%), and amylose content (26.29-29.37\%) of buru hotong phosphate flour compared with native flour. The characteristics of phosphate hotong flour were different from their native. The higher the concentration of STPP, all of the variables were increases.
\end{abstract}

Keywords: sodium tripolyphosphate, buru hotong phosphate flour, physicochemical properties

\begin{abstract}
ABSTRAK
Penelitian ini bertujuan untuk mengkarakterisasi tepung buru hotong fosfat yang dimodifikasi dengan menggunakan sodium tripolyphosphate (STPP). Tepung buru hotong difosforilasi pada suhu $45^{\circ} \mathrm{C}$ dengan konsentrasi STPP 10, 15, 20 dan 25\% selama 30 menit. Pengamatan dilakukan terhadap sifat fisiko-kimia tepung buru hotong alami dan derivatnya, meliputi kadar fosfor, derajat substitusi (DS), kadar air, kadar abu, daya gelembung, daya larut, dan kadar amilosa. Hasil penelitian menunjukkan bahwa kadar fosfor tepung buru hotong fosfat meningkat $(0,023-0,077 \%)$ dengan kisaran DS antara 0,001-0,004. Kadar fosfor dan DS menunjukkan terjadinya substitusi gugus fosfat. Tersubstitusinya gugus fosfat menyebabkan meningkatnya kadar air $(6,92-10,23 \%)$, kadar abu $(0,37-0,84 \%)$, daya gelembung $(10,16-15,63 \%)$, daya larut $(29,22-$ $46,2 \%)$ dan kadar amilosa (26,29-29,37\%) tepung buru hotong fosfat dibandingkan dengan tepung buru hotong alami. Karakteristik tepung buru hotong fosfat berbeda dengan tepung alaminya. Semakin tinggi konsentrasi STPP maka setiap peubah yang dialami mengalami peningkatan.
\end{abstract}

Kata kunci: Sodium tripolyphosphate, tepung buru hotong fosfat, sifat-sifat fisiko-kimia 


\section{PENDAHULUAN}

Masyarakat Indonesia masih mengkonsumsi beras sebagai makanan pokok. Ketergantungan masyarakat pada beras telah menimbulkan masalah dalam sistem ketahanan pangan di Indonesia, oleh karena itu program-program diversifikasi pertanian dan usaha penganekaragaman bahan pangan lokal yang dilakukan oleh pemerintah untuk mengurangi ketergantungan masyarakat terhadap beras perlu mendapat perhatian yang serius. Salah satu contoh sumber bahan pangan lokal di Pulau Buru yang dikembangkan adalah tanaman hotong (Setaria italica L Beauv.) (Sugiyono et al., 2010). Masyarakat Pulau Buru lebih mengenalnya dengan nama buru hotong. Buru hotong termasuk salah satu jenis tanaman pangan unggul lokal yang dikonsumsi oleh masyarakat Pulau Buru sebagai pangan alternatif penghasil karbohidrat. Herodian (2008) mengemukanan bahwa kadar karbohirdat buru hotong relatif sama dengan beras di Indonesia, yaitu sekitar $82 \%$. Biji buru hotong memiliki nilai ekonomis penting antara lain sebagai bahan baku pembuatan mi instan (Sugiyono et al., 2010) cookies dan bubur instan (Herodian, 2008).

Kandungan nutrisi biji buru hotong cukup tinggi yaitu mengandung protein sebesar $14,05 \%$, lemak 3,37\%, karbohidrat $81,32 \%$, air sebesar $9,03 \%$, dan abu sebesar 1,26\% (Herodian, 2008). Sedangkan menurut Rokhani et al. (2003), biji buru hotong memiliki kandungan protein dan lemak masing-masing sebesar $11,2 \%$ dan $2,4 \%$. Energi yang dihasilkan dalam $100 \mathrm{~g}$ biji adalah 359 kalori. Dilihat dari kandungan gizinya yang cukup tinggi maka tanaman buru hotong dapat dijadikan komoditi alternatif dalam program diversifikasi pangan penghasil karbohidrat (Herodian, 2008), untuk itu perlu dibudidayakan secara luas serta dijaga kelestariannya sebagai komoditi unggul lokal.

Tanaman buru hotong belum dikenal secara luas oleh masyarakat Indonesia dan pengolahannya juga masih terbatas. Tanaman ini ditanam dan dibudidayakan secara terbatas di Pulau Buru, Provinsi Maluku. Ketertarikan pemanfaatan buru hotong disebabkan karena mengandung komponen bioaktif yang mempunyai sifat antioksidan, antara lain adalah tanin dan vitamin E. Pemanfaatan buru hotong masih terbatas pada pembuatan nasi hotong dan waji hotong, yang adalah informasi dari warga setempat. Perkembangan sekarang ini, masyarakat Pulau Buru, mulai mengolah buru hotong menjadi tepung sebagai produk antara untuk selanjutnya digunakan sebagai bahan dasar untuk pengolahan lebih lanjut. Informasi tentang sifat-sifat kimia buru hotong telah diteliti oleh Herodian (2008) dan Rokhani et al. (2003), tetapi informasi tentang pemanfaatan tepung hotong lebih lanjut masih sangat sedikit, terlebih lagi informasi tentang modifikasi tepung menggunakan reagen modifikasi. Perlakuan modifikasi pada tepung buru hotong tergolong masih baru, ditujukan untuk mempelajari apakah teknik modifikasi yang digunakan dapat mengubah sifat tepung buru hotong.

Modifikasi yang telah dilakukan antara lain secara fisik, kimia dan enzimatis. Modifikasi secara kimiawi merupakan salah satu alternatif, dan dapat dilakukan dengan cara eterifikasi, esterifikasi, cross-linking, dekomposisi asam, hidrolisa dengan menggunakan enzim, dan oksidasi. Modifikasi kimia merupakan reaksi kimia antara gugus hidroksil pati dengan senyawa kimia tertentu, salah satunya yaitu dengan mereaksikan molekul pati dengan sodium tripolyphosphate (STPP). Modifikasi ini dapat membentuk monostarch phosphate jika hanya satu gugus hidroksil dari pati yang bereaksi dengan fosfat yang berupa reaksi substitusi maupun distarch phosphate jika dua buah gugus hidroksil bereaksi dengan fosfat yang berupa reaksi crosslinking (Polnaya et al., 2013). Substitusi bertujuan untuk menstabilkan pati dengan mencegah reasosiasi atau retrogradasi. Crosslinking membentuk ikatan kimia yang lebih kuat sehingga saat suhu suspensi dinaikkan granula akan tetap utuh. Kelebihan dari pati crosslinking adalah suhu gelatinisasi pati menjadi meningkat, pati tahan pada $\mathrm{pH}$ rendah dan pengadukan (Widhaswari dan Putri, 2014). Selain itu Lu et al. (2012) mengemukakan bahwa fosfor pada kentang merupakan faktor penting yang mempengaruhi sifat-sifat pati kentang jika dibandingkan dengan kadar amilosanya.

Beberapa hasil penelitian menunjukkan bahwa fosforilasi pati menyebabkan perubahan sifat-sifat pati alami seperti pada pati sagu fosfat (Polnaya et al., 2012; 2013; 2018), pati ubi jalar oranye (Retnaningtyas dan Widya, 2014) dan tepung ubi jalar ungu (Widhaswari dan Putri, 2014). Konsentrasi STPP yang umumnya digunakan adalah sebesar 1-10\% (Cornelia dan Christianti, 2017; Rahim et al., 2013; Polnaya et al., 2012). Penggunaan konsentrasi STPP $1 \%$ dan lama perendaman 1 jam menghasilkan pati dengan swelling power dan solubilitas yang terbaik 
(Widhaswari dan Putri, 2014). Fosforilasi dengan STPP menyebabkan ikatan pati menjadi kuat, tahan terhadap pemanasan, dan asam sehingga dapat menurunkan derajat pembentukan granula, dan meningkatkan stabilitas adonan, karena adanya ikatan antara pati dengan fosfat diester atau ikatan silang antar gugus -OH. Kondisi optimum proses modifikasi didasarkan pada reaksi yang terjadi antara gugus fungsional dalam STPP dengan pati agar tercapai tujuan modifikasi yang diinginkan, yaitu viskositas agar lebih stabil serta memperkecil retrogradasinya. Reaksi yang terjadi dipengaruhi oleh banyaknya kosentrasi STPP yang ditambahkan dalam proses modifikasi.

\section{METODE PENELITIAN}

\section{Bahan}

Bahan yang digunakan dalam penelitian ini adalah tepung hotong $1,5 \mathrm{~kg}$ yang diperoleh dari desa Kilo 7, Kabupaten Buru Selatan, Maluku. Reagen modifikas STPP (food grade) yang dibeli dari toko bahan kimia. Semua bahan kimia tersebut adalah pure analysis.

Rancangan percobaan yang digunakan adalah rancangan acak lengkap satu faktor dengan lima taraf perlakuan dan tiga kali ulangan. Perlakuan STPP meliputi konsentrasi 10, 15, 20, dan 25\%. Tepung buru hotong yang tidak mendapat perlakuan atau disebut tepung buru hotong alami atau perlakuan STPP 0\%, digunakan sebagai pembanding. Penelitian ini dilakukan di laboratorium Teknologi Hasil Pertanian, Fakultas Pertanian, Universitas Pattimura.

\section{Fosforilasi Tepung Buru Hotong}

Tepung buru hotong sebanyak $30 \mathrm{~g}$ disuspensi dalam $45 \mathrm{~mL}$ akuades, dan selanjutnya diatur pH-nya menjadi 9 dengan menambahkan $\mathrm{NaOH} 1 \mathrm{M}$ (Merck, Germany) sambil diaduk. STPP sebanyak 10\% ditambahkan sedikit demi sedikit kedalam suspensi sambil diaduk. Suspensi kemudian dipanaskan pada suhu $45^{\circ} \mathrm{C}$ selama 30 menit. Selanjutnya bubur tepung yang didapatkan dinetralkan sampai $\mathrm{pH}$ 6,5 dengan penambahan $\mathrm{HCl} 1 \mathrm{M}$ (Merck, Germany). Tepung yang telah difosforilasi dicuci sebanyak tujuh kali dengan penambahan $45 \mathrm{~mL}$ akuades. Tepung fosfat kemudian dikeringkan pada suhu $40^{\circ} \mathrm{C}$ selama 12 jam. Tepung fosfat kasar digiling dan diayak dengan ayakan 80 mesh. Prosedur yang sama juga dilakukan untuk perlakuan tanpa penambahan STPP dan konsentrasi STPP 15, 20, dan $25 \%$. Tepung buru hotong fosfat yang diperoleh selanjutnya dikemas dalam kemasan plastik dan disimpan pada suhu $4^{\circ} \mathrm{C}$. Analisis tepung buru hotong fosfat meliputi kadar fosfor, derajat substitusi (DS), kadar air, kadar abu, kadar amilosa, daya gelembung, dan daya larut.

\section{Analisis kadar fosfor}

Analisis kadar fosfor berdasarkan metode Molibdat-Vanadat seperti yang dikemukakan oleh (Smith dan Caruso, 1964). Sampel ditimbang sebanyak $20 \mathrm{~g}$ dan masukan ke dalam cawan dan ditambakan $10 \mathrm{~mL}$ larutan zinc asetat $(10 \%, \mathrm{~b} / \mathrm{v})$ (Merck, Germany). Sampel dievaporasi sampai kering menggunakan oven pada suhu $105{ }^{\circ} \mathrm{C}$ (Memmert, Germnay) dan arangkan sampel di ruang asam, sampai tidak berasap. Sampel diabukan di dalam muffle furnace (Vulcan A-550 Ney, USA) pada suhu $550{ }^{\circ} \mathrm{C}$ selama 30 menit. Dinginkan pada suhu kamar, kemudian cawan dicuci dengan $10 \mathrm{~mL}$ asam nitrat $(29 \% \mathrm{v} / \mathrm{v})$ (Merck, Germany) dan $15 \mathrm{~mL}$ akuades. Larutan tersebut dipanaskan sampai mendidih dan ditahan selama 10 menit dalam ruang asam. Setelah didinginkan sampai tidak menguap, lalu saring larutan dengan kertas saring, kemudian masukan ke dalam labu takar $100 \mathrm{~mL}$ dan encerkan sampai tanda tera (filtrasi diencerkan sehingga kandungan fosfor kurang dari 2,5 mg). Kemudian, ambil 25 $\mathrm{mL}$ alikuot dan masukan ke dalam labu takar 100 $\mathrm{mL}$, ditambahkan $10 \mathrm{~mL}$ asam nitrat (29\%, v/v), $10 \mathrm{~mL}$ ammonium vanadate $(0,25 \%$, v/v) (Merck, Germany), dan $10 \mathrm{~mL}$ ammonium molibdat (5\%, v/v), kemudian encerkan dengan akuades sampai $100 \mathrm{~mL}$. Setelah dicampur dibiarkan selama 10 menit. Pembacaan absorbansi dilakukan pada panjang gelombang $460 \mathrm{~nm}$. Kandungan fosfor sampel ditentukan berdasarkan kalibrasi kurva standar.

\section{Derajat Substitusi}

Derajat Substitusi tepung hotong fosfat ditentukan berdasarkan perhitungan yang dikemukakan oleh (Polnaya et al., 2013):

$$
\mathrm{DS}=\frac{(162 \times P)}{[(3100-(103 \times P)}
$$

dimana $P$ merupakan kadar fosfor (\%), 162 merupakan berat molekul satuan hidro glukosa, 
3100 merupakan berat atom fosfor dikalikan dengan 100, dan 103 berat molekul gugus fosfat $\left(\mathrm{NaPO}_{3}\right)$ pada pati fosfor.

\section{Kadar Air}

Analisis kadar air mengacu pada metode gravimetri AOAC 925.10 (2012). Sebanyak $1 \mathrm{~g}$ sampel tepung dimasukkan dalam botol timbang yang telah diketahui berat konstannya. Sampel dipanaskan dalam oven (Memmert, Germany) pada suhu $105^{\circ} \mathrm{C}$ pada suhu $105^{\circ} \mathrm{C}$, didinginkan dalam desikator dan ditimbang sampai berat konstan. Perhitungan kadar air sampel didasarkan pada perbedaan berat sebelum dan sesudah sampel dikeringkan.

\section{Kadar Abu}

Analisis kadar abu mengacu pada metode AOAC 923.03 (AOAC, 2012). Sebanyak $5 \mathrm{~g}$ sampel tepung dimasukan dalam cawan porselin yang telah dikeringkan dan ketahui beratnya. Sampel dibakar dengan pemanas listrik sampai sampai sampel tidak berasap dan diabukan pada tanur pengabuan (Vulcan A-550 Ney, USA) pada suhu $650^{\circ} \mathrm{C}$ sampai dihasilkan abu yang berwarna putih keabu-abuan dan beratnya telah konstan. Kadar abu sampel ditentukan dengan menimbang sisa mineral hasil pembakaran bahan organik.

\section{Kadar Amilosa}

Analisis kadar amilosa mengacu pada Wulandari et al. (2019). Sebanyak $100 \mathrm{mg}$ sampel tepung di tempatkan ke dalam tabung reaksi 50 mL, setelah itu ditambahkan $1 \mathrm{~mL}$ etanol $95 \%$ (Sigma-Aldrich, Germany) dan $9 \mathrm{~mL} \mathrm{NaOH} 1 \mathrm{M}$ (Merck, Germany) lalu dihomogenkan dengan divortex. Campuran dipanaskan dalam penangas air mendidih selama 10 menit, kemudian diencerkan hingga $100 \mathrm{~mL}$. Sebanyak $5 \mathrm{~mL}$ larutan sampel dimasukan kedalam labu takar $100 \mathrm{~mL}$ dan ditambahkan dengan $1 \mathrm{~mL}$ larutan asam asetat $1 \mathrm{~N}$ (Merck, Germany) dan $2 \mathrm{~mL}$ larutan Iod 0,01 N (Merck, Germany), dan akuades sampai batas tera. Larutan dipanaskan dengan penangas air pada suhu $30^{\circ} \mathrm{C}$ selama 20 menit. Intensitas warna biru yang terbentuk diukur absorbansinya dengan UV-Vis spektrofotometer (Genesys $10 \mathrm{~S}$, China) pada $\lambda$ $620 \mathrm{~nm}$. Absorbansi yang diperoleh diplotkan pada kurva standar dan kadar amilosa dihitung berdasarkan hubungan absorbansi sampel dengan kadar amilosa pada pada kurva standar.

\section{Daya Gelembung Dan Daya Larut Tepung}

Analisis daya gelembung dan daya larut mengacu pada metode yang dikemukakan oleh Tattiyakul et al. (2012). Tepung disuspensi dalam akuades $(1 \%, \mathrm{~b} / \mathrm{v})$ dalam tabung reaksi yang telah diketahui beratnya $\left(w_{l}\right)$. Kemudian dipanaskan pada penangas air (Memmert, Germany) pada suhu $95^{\circ} \mathrm{C}$ selama 30 menit, lalu didinginkan hingga suhu kamar $\left(27^{\circ} \mathrm{C}\right)$. Selanjutnya gel pati disentrifugasi (Hermle, Germany) pada 5000 rpm selama 15 menit, sehingga terpisah residu dan supernatant. Residu hasil sentrifugasi kemudian di timbang $\left(w_{2}\right)$. Daya gelembung pati (berdasarkan berat kering) ditentukan sebagai berikut:

$$
\text { Daya gelembung }(\mathrm{g} / \mathrm{g})=\frac{\left(w_{2}-w_{1}\right)}{\text { berat pati }}
$$

Alikuot $(10 \mathrm{~mL})$ dari supernatan dikeringkan, hingga berat konstan pada suhu $110^{\circ} \mathrm{C}$. Residu yang diperoleh setelah pengeringan supernatan, menunjukkan jumlah pati yang terlarut dalam air (\%).

\section{Analisis statistik}

Penelitian menggunakan rancangan acak lengkap dengan tiga ulangan. Uji Tukey pada taraf 95\% $(\alpha=0,05)$ digunakan untuk mengetahui perbedaan di antara rataan perlakuan tersebut. Data dianalisis menggunakan analisis keragaman dengan bantuan program Minitab 18.

\section{HASIL DAN PEMBAHASAN}

\section{Kadar Fosfor}

Hasil analisis ragam menunjukkan bahwa perlakuan konsentrasi STPP berpengaruh sangat nyata $(P<0,01)$ terhadap kadar fosfor tepung buru hotong termodifikasi fosfat. Kadar fosfor tepung buru hotong fosfat berkisar antara 0,023-0,077\% (bk), sedangkan tepung buru hotong alami tidak mengandung fosfor (Tabel 1). Hasil penelitian yang relatif sama ditunjukkan oleh beberapa peneliti lainnya, seperti pada pati apple wolf fosfat kadar fosfornya adalah 0,015-0,397\% (Ascheri et al., 2014), dan pati labu 0,295-0,519\% (Roznowski et al., 2016). Hasil penelitian sebelumnya menunjukkan bahwa terjadi peningkatan kadar fosfor. Kadar fosfor tepung buru hotong meningkat 
seiring dengan meningkatnya konsentrasi STPP. Hal ini disebabkan karena semakin tinggi konsentrasi reagen yang digunakan maka semakin tinggi konsentrasi garam fosfat yang tersedia, sehingga peluang gugus fosfat yang tersubstitusi pada tepung buru hotong akan semakin besar. Kadar karbohidrat yang tinggi dari tepung buru hotong (Herodian, 2008) memungkinkan ketersediaan gugus $\mathrm{OH}$ pada rantai molekul amilosa pati untuk dapat disubstitusi oleh gugus fosfat. Hal ini menunjukkan bahwa terikatnya gugus fosfor hanya terjadi pada rantai molekul pati, bukan yang lainnya

\section{Derajat Substitusi}

Perhitungan nilai DS dihitung berdasarkan kadar fosfor, sehingga terdapat hubungan yang erat antara kedua nilai tersebut berdasarkan persamaan yang dikemukakan oleh Sing dan Nath (2011). DS tepung buru hotong fosfat berkisar antara 0,0010,004\% (Tabel 1). Meningkatnya kosentrasi STPP atau kadar fosfor menyebabkan peningkatan nilai DS tepung buru hotong. Hal ini sejalan dengan penelitian yang dilakukan pada tepung kacang tunggak merah, oleh Hustiany (2014), pati aren dengan nilai DS 0,040-0,065\% (Rahim et al., 2013), dan pati sagu dengan nilai DS 0,0004-0,018 (Polnaya et al., 2013). Hasil penelitian terlihat bahwa nilai DS secara langsung dipengaruhi oleh kadar fosfor.

\section{Kadar Air}

Perlakuan konsentrasi STPP berpengaruh sangat nyata $(P<0,01)$ terhadap kadar air tepung buru hotong fosfat. Kadar air tepung buru hotong alami adalah sebesar 5,96\% relatif lebih rendah dari penelitian Herodian (2008) yaitu sebesar $6,82 \%$. Modifikasi tepung buru hotong fosfat dengan menggunakan STPP menyebabkan perubahan kadar air. Kadar air tepung buru hotong hasil modifikasi dengan STPP berkisar antara 5,96$10,23 \%$. Semakin tinggi perlakuan konsentrasi STPP, maka kadar air tepung buru hotong semakin meningkat (Tabel 1). Hasil ini relatif sama dengan penelitian pada pati umbi gembili, $(0,25-5,17 \%)$ (Herlina, 2010), pada tepung ubi jalar oranye (6,37-6,86\%) (Aulia dan Putri, 2015) dan pada pati ubi jalar orange $(9,98-13,38)$ (Retnaningtyas dan Widya, 2014). Meningkatnya kadar air tepung buru hotong fosfat disebabkan karena sifat gugus fosfat yaitu hidrofilik (ion yang suka air). Fraksi fosfat mampu mengikat air menyebabkan kemampuan pengikat air oleh pati menjadi lebih tinggi (Polnaya et al., 2012; Widhaswari dan Putri, 2014). Gugus fosfat yang tersubstitusi ke dalam tepung buru hotong akan membentuk kelompok fosfat yang mempunyai kemampuan daya serap air yang besar, karena fosfat yang tersubstitusi memiliki muatan negatif yang memfasilitasi penetrasi dan penyerapan air (Polnaya et al., 20112; Rahim et al., 2019).

\section{Kadar Abu}

Kadar abu tepung buru hotong alami adalah sebesar 0,25\% (bk). Hasil penelitian (Herodian, 2008) menunjukkan nilai kadar abu lebih besar yaitu $0,97 \%$. Kadar abu tepung buru hotong fosfat berkisar antara $0,37-0,84 \%$ (Tabel 1) lebih tinggi dari tepung buru hotong alaminya $(0,25 \%)$, tetapi lebih rendah dibandingkan penelitian Herlina (2010) yang menunjukkan kadar abu pati gembili fosfat adalah 1,43-1,89\%. Dari hasil analisis menunjukkan bahwa semakin tinggi konsentrasi STPP semakin tinggi kadar abu tepung buru hotong fosfat. Hasil ini relatif sama dengan penelitian Aulia dan Putri (2015) untuk pati tepung ubi jalar oranye dan (Cornelia dan Christianti, 2017) pada pati biji alpukat. Meningkatnya kadar abu tepung buru hotong fosfat disebabkan karena gugus $\mathrm{OH}$ tersubstitusi oleh gugus fosfat selama modifikasi (Polnaya et al., 2012). Semakin banyak gugus fosfat yang terikat, semakin banyak kandungan abu. Widhaswari dan Putri (2014) mengemukakan bahwa gugus fosfat merupakan komponen penyusun abu.

\section{Kadar Amilosa}

Kadar amilosa tepung buru hotong alami adalah sebesar 26,12\% dan relatif sama dengan hasil penelitian (Herodian, 2008). Kadar amilosa tepung buru hotong alami adalah lebih rendah dibandingkan derivatnya. Kadar amilosa tepung buru hotong termodifikasi fosfat tertinggi yaitu perlakuan konsentrasi STPP 25\% sebesar 29,37\%. Hasil penelitian menunjukkan bahwa nilai rataan kadar amilosa tepung buru hotong fosfat berkisar antara 26,12-29,37\%. Hasil ini menunjukkan bahwa kadar amilosa tepung buru hotong fosfat meningkat seiring dengan tingginya kadar STPP atau meningkatnya nilai DS. Hal ini sama dengan peneliti lainnya. Retnaningtyas dan Widya (2014) menyatakan semakin tinggi konsentrasi STPP akan 
menyebabkan kadar amilosa pati ubi jalar oranye semakin meningkat. Molekul amilosa pada rantai bercabang bersifat lebih mudah mengalami fosforilasi, sehingga molekul amilopektin saling bergabung menghasilkan sedikit molekul dalam ukuran yang besar sehingga menyebabkan proporsi amilosa terhadap amilopektin meningkat. Selain itu, menurut Mbougueng et al. (2012), degradasi molekul amilopektin berupa molekul linier dan heliks ganda mempengaruhi peningkatan pengikatan terhadap iod lebih baik dibandingkan sebelum modifikasi, dan hal ini mempengaruhi analisis kadar amilosa.

\section{Daya Gelembung}

Daya gelembung tepung buru hotong hasil modifikasi berkisar antara 10,16-15,63g/g. Semakin tinggi konsentrasi STPP, daya gelembung tepung buru hotong semakin meningkat (Tabel 2). Hal yang sama juga dilaporkan oleh Ascheri et al. (2014) pada pati apple wolf. Latifa et al. (2017) juga mengemukakan bahwa semakin meningkatnya konsentrasi monostrach phosphate dapat meningkatkan daya gelembung pati. Peningkatan daya gelembung disebabkan karena tersbstitusinya gugus $\mathrm{OH}$ oleh gugus fosfat, menyebabkan melemahnya ikatan hidrogen dan interaksi molekul air dengan gugus $\mathrm{OH}$ amilosa dan amilopektin, sehingga memudahkan terjadinya penggelembungan. Meningkatnya daya gelembung juga berhubungan dengan kemampuan daya serap air tepung buru hotong fosfat. Gugus fosfat yang mempunyai kemampuan daya serap air yang besar, yang memfasilitasi penetrasi dan penyerapan air.

\section{Daya Larut}

Tabel 2 menunjukkan bahwa semakin tinggi konsentrasi STPP, dapat meningkatkan daya larut dari tepung buru hotong fosfat. Hal ini sejalan dengan penelitian (Polnaya et al., 2013) yaitu semakin tinggi rasio fosfat yang ditambahkan akan meningkatkan daya larut pati sagu pada $\mathrm{pH}$ reaksi optimumnya. Menurut Polnaya et al. (2013), apabila $\mathrm{pH}$ reaksi meningkat, dapat menyebabkan reaksi pati dengan STPP menghasilkan distarch phosphate dan menyebabkan daya larut pati menurun. Meningkatnya kelarutan tepung buru hotong fosfat dapat disebabkan gugus fosfat. Gugus fosfat yang bermuatan negatif dapat menurunkan kekuatan ikatan antar molekul, sehingga menyebabkan kemudahan tepung buru hotong fosfat untuk larut dalam air panas. Hasil penelitian Rahim et al. (2019) tidak sejalan dengan hasil penelitian ini. Daya larut pati aren fosfat semakin menurun dengan meningkatnya konsentrasi monostrach phosphate. Perbedaan ini disebabkan karena perbedaan reagen modifikasi yang digunakan. Penambahan STMP pada penelitian Rahim et al. (2019) menyebabkan terjadinya ikat silang atau distarch phosphate dan bukan lagi monostarch phosphate.

Tabel 1. Karakteristik kimia tepung buru hotong fosfat yang dihasilkan dengan penambahan STPP

\begin{tabular}{lccccc}
\hline \multirow{2}{*}{ Variabel } & \multicolumn{5}{c}{ Konsentrasi STPP $(\% \mathrm{~b} / \mathrm{b})$} \\
\cline { 2 - 6 } & 0 & 10 & 15 & 20 & 25 \\
\hline Kadar Fosfor (\%) & $0 \mathrm{e}$ & $0,023 \mathrm{~d}$ & $0,04 \mathrm{c}$ & $0,58 \mathrm{~b}$ & $0,77 \mathrm{a}$ \\
Derajat Substitusi (\%) & $0 \mathrm{e}$ & $0,001 \mathrm{~d}$ & $0,002 \mathrm{c}$ & $0,003 \mathrm{~b}$ & $0,004 \mathrm{a}$ \\
Kadar Air (\%) & $5,96 \mathrm{e}$ & $6,92 \mathrm{~d}$ & $9,7 \mathrm{c}$ & $9,92 \mathrm{~b}$ & $10,23 \mathrm{a}$ \\
Kadar Abu (\%) & $0,25 \mathrm{e}$ & $0,37 \mathrm{~d}$ & $0,6 \mathrm{c}$ & $0,72 \mathrm{~b}$ & $0,84 \mathrm{a}$ \\
Kadar Amilosa (\%) & $26,2 \mathrm{~b}$ & $26,29 \mathrm{~b}$ & $27,22 \mathrm{~b}$ & $27,98 \mathrm{ab}$ & $29,37 \mathrm{a}$ \\
\hline
\end{tabular}

Keterangan: Angka yang diikuti huruf yang sama pada baris yang sama menunjukkan tidak berbeda nyata berdasarkan uji Tukey $(\alpha=0,05)$.

Tabel 2. Karakteristik fisik tepung buru hotong fosfat yang dihasilkan dengan penambahan STPP

\begin{tabular}{lccccc}
\hline \multirow{2}{*}{ Variabel } & \multicolumn{5}{c}{ Konsentrasi STPP $(\%, \mathrm{~b} / \mathrm{b})$} \\
\cline { 2 - 6 } & 0 & 10 & 15 & 20 & 25 \\
\hline Daya Gelembung $(\mathrm{g} / \mathrm{g})$ & $9,34 \mathrm{~d}$ & $10,16 \mathrm{~d}$ & $11,38 \mathrm{c}$ & $13,72 \mathrm{~b}$ & $16,63 \mathrm{a}$ \\
Daya Larut (\%) & $20,54 \mathrm{e}$ & $29,22 \mathrm{~d}$ & $36,52 \mathrm{c}$ & $40,72 \mathrm{~b}$ & $46,2 \mathrm{a}$ \\
\hline
\end{tabular}

Keterangan: Angka yang diikuti huruf yang sama pada baris yang sama menunjukkan tidak berbeda nyata berdasarkan uji Tukey $(\alpha=0,05)$. 


\section{KESIMPULAN}

Perlakuan modifikasi fosfat dengan menggunakan STPP menghasilkan tepung buru hotong fosfat, dengan karakteristik yang berbeda dibandingkan tepung buru hotong alaminya. Konsentrasi fosfor dan DS tepung buru hotong fosfat lebih tinggi dibandingkan dengan tepung alaminya, dan meningkat seiring meningkatkan konsentrasi STPP yang diperlakukan. Tersubstitutinya gugus -OH oleh gugus fofat meningkatkan beberapa sifat yang di amati meliputi kadar air, kadar abu, dan kadar amilosa. Daya gelembung dan daya larut tepung buru hotong fosfat juga meningkat.

\section{UCAPAN TERIMA KASIH}

Penulis mengucapkan terima kasih kepada petani buru hotong di Pulau Buru yang telah menyediakan buru hotong sebagai bahan penelitian. Terima kasih juga kepada Saldri V. Nivaan, yang telah membantu penulis dalam mempreparasi dan menganalisis tepung buru hotong dan derivatifnya.

\section{DAFTAR PUSTAKA}

[AOAC] Association of Official Analytical Chemists. 2012. Official Methods of Analysis of The Association of Official Analytical Chemists. AOAC Inc. Arlington, Virginia.

Ascheri, D., L. Pereira, and S. Bastos. 2014. Chemical, morphological, rheological, and thermal properties of Solanum lycocarpum phosporylated starches. Rev. Cere. Vicosa. 61: 458-466.

Aulia, R., dan W. Putri. 2015. Karakteristik sifat fisikokimia tepung ubi jalar oranye hasil modifikasi kimia dengan STPP. Jurnal Pangan dan Agroindustri 3: 476-482.

Cornelia, M., and A. Christianti. 2017. Utilization of modified starch from avocado (Persea americana Mill.) seed in cream soup production. International Symposium on Food and Agro-biodiversity 102: Earth and Environmental Science. DOI:10.1088/17551315/102/1/012074.

Herlina. 2010. Karaktersitiksifat fisik, kimia, dan fungsional bahan pati gembili (Dioscorea esculenta L.) termodifikasi secara ikat silang dengan Natrium Tripolifosfat. AGROTEK 4:
60-67.

Herodian, S. 2008. Oktober-Desember. Pengembangan buru hotong (Setaria italica (L.) Beauv) sebagai sumber pangan pokok alternatif. Jurnal Pangan 17: 26-37.

Hustiany, R. 2014. Characteristics of crosslink acylation tapioca substituted nagara beans (Vigna unguiculata spp Cylindrica) flour. Agroindustrial Journal 3: 125-132.

Latifah, H., dan Yunianta. 2017. Modifikasi pati garut metode ganda dan aplikasinya sebagai pengental. Jurnal Pangan dan Agroindustri 5: 31-41.

Lu, Z.-H., E. Donner, R.Y. Yada, and Q. Liu. 2012. The synergistic effects of amylose and phosphorus on rheological, thermal and nutritional properties of potato starch and gel. Food Chemistry 133: 1214- 1221.

Maulani, R.R., D. Fardiaz, F. Kusnandar, and T.C. Sunarti. 2013. Characterization of chemical and physical properties of hydroxypropylated and cross-linked arrowroot (Marantha arundinacea) starch. Journal of Engineering and Technological Sciences 45: 207-221.

Mbougueng, P.D., D. Tenin, J. Scher, and C. Tchiégang. 2012. Influence of acetylation on physicochemical, functional and thermal properties of potato and cassava starches. Journal of Food Engineering 108: 320-326. doi:10.1016/j.jfoodeng.2011.08.006

Polnaya, F., D. Haryadi, Marseno, and M. Cahyanto. 2012. Preparation and properties of Phosphorylated sago starcesh. Sago Palm 20: 3-11.

Polnaya, F., Haryadi, D.W. Marseno, and M.N. Cahyanto. 2013. Effect of phophorilation and cross-linking on the pasting properties and molecular structure of sago starch. International Food Research Journal 20: 1609-1615.

Polnaya, F.J., Haryadi, D.W. Marseno, and M.N. Cahyanto. 2018. Physical properties and digestibility of resistant starch from from phosphorilated sago starches. Pakistan Journal of Nutrition 17. DOI: 10.3923/pjn.2018.199.206

Rahim, A., G. Hutomo, and Jusman. 2013. Effect of phosphorylation on the physical and chemical characteristics of arenga starch. International Journal of Biology, Pharmacy and Allied Sciences 2: 1973-1985.

Rahim, A., Sukmawati, S. Kadir. Jusman, Rahmi, 
dan If'all. 2019. Karakteristik fisikokimia pati aren fosfat asetat fosfat pada berbagai konsentrasi natrium trimetafosfat dan tripolifosfat. Buletin Palma 20: 119-125. DOI: 10.21082/bp.v20n2.2019.119-125

Retnaningtyas, D. dan D. Widya. 2014. Karakteristik sifat fisiko-kimia pati ubi jalar oranye hasil perlakuan STPP (Lama Perendaman dan konsentrasi). Jurnal Pangan dan Agroindustri 2: 68-77.

Rokhani, H., Sutrisno, dan S. Herodian. 2003. Teknologi pengolahan hermada dalam rangka diversifikasi usaha tani hotong. Lokakarya Pengembangan Hotong. Jakarta: Dinas Pertanian dan Kehutanan DKI Jakarta.

Roznowski, J., I. Przetaczek-Roznowski, and D. Boba. 2016. Physicochemical properties of native and phosphorylated pumpkin starch. Starch/Stráke 69: 1-8. DOI: 10.1002/star.201500358

Smith, R., and J. Caruso. 1964. Determination of phosphorous. In R. Whistler, Methods in Carbohydrate Chemistry. New York: Academic Press.
Sugiyono, S. Wibowo, S. Koswara, S. Herodian, S. Widowati, dan B. Santoso. 2010. Pengembangan produk mie instan dari tepung hotong (Setaria italica Beauv.) dan pendugaan umur simpannya dengan metode akselerasi. Jurnal Teknologi dan Industri Pangan 21: 45-50.

Tattiyakul, J., T. Naksriarporn, and P. Pradipasena. 2012. X-ray diffraction pattern and functional properties of Dioscorea hispida Dennst starch hydrothermally modified at different temperatures. Food Bioprocess Technology 5: 964-971. DOI: 10.1007/s1 1947-010-0424-3

Widhaswari, V. dan W. Putri. 2014. Pengaruh modifikasi kimia dengan STPP terhadap karakteristik tepung ubi jalar ungu. Jurnal Pangan dan Agroindustri 2: 121-128.

Wulandari, E., E. Sukarminah, E. Mardawati, dan H.L. Furi. 2019. Profil gelatinisasi tepung sorgum putih termodifikasi $\alpha$-amilase. Jurnal Teknologi Industri Pangan 30: 173179. DOI: 10.6066/jtip.2019.30.2.173

This work is licensed under a Creative Commons Attribution-ShareAlike 4.0 International License. 